\title{
Pembelajaran Komposisi Musik Sekolah Melalui Pemanfaatan Perkakas Tangan
}

\author{
Yudi Sukmayadi ${ }^{1}$ \\ Departmen Pendidikan Musik, Universitas Pendidikan Indonesia (UPI) Bandung
}

Arif Purnama

Sekolah Menengah Kejuruan Merdeka Bandung

\begin{abstract}
ABSTRAK
Artikel ini mendeskripsikan model pembelajaran komposisi musik sekolah dengan memanfaatkan perkakas tangan sebagai media kreativitasnya. Penelitian yang dilakukan di Sekolah Menengah Kejuruan Negeri (SMKN) 12 Bandung ini mengungkap tentang rancangan, implementasi, dan efektivitas model pembelajaran, serta upaya pencapaian tujuan untuk meningkatkan dan mengembangkan kompetensi musikal siswa. Penelitian ini menggunakan action research. Data dikumpulkan melalui observasi, wawancara, studi dokumentasi dengan berbasis pada kegiatan eksperimen musik. Hasil penelitian menunjukkan bahwa model pembelajaran komposisi musik sekolah dengan mendayagunakan keunikan sekolah kejuruan yakni penggunaan perkakas tangan sebagai media kreativitas siswa, sangat efektif dan efisien dalam mengembangkan proses pembelajaran seni musik, khususnya dalam membangun dan mengembangkan kompetensi musikal siswa.
\end{abstract}

Kata kunci: model pembelajaran, komposisi musik sekolah, perkakas tangan

\begin{abstract}
Learning of Music Education Composition Through Utilization of Hand Tools. This article describes the learning model of music education composition by utilizing hand tools as media of creativity. The research conducted at Bandung 12th Vocational Middle School (SMKN) which revealed about the design, implementation, and effectiveness of learning models, as well as efforts to achieve the goals to improve and develop students' musical competencies. This study used action research. Data was collected through observation, interviews, documentary studies based on musical experiment activities. The results show that the learning model of music education composition by utilizing the uniqueness of vocational schools namely the use of hand tools as media for students' creativity is very effective and efficient in developing the learning process of musical art, especially in building and developing students' musical competencies.
\end{abstract}

Keywords: music learning, school music composition, music hand tools

\section{Pendahuluan}

Berdasarkan data dan fakta empirik yang diperoleh dari hasil studi pendahuluan lapangan, dalam proses pembelajaran seni budaya (seni musik) di Sekolah Menengah Kejuruan Negeri (SMKN) 12 Bandung masih terdapat beberapa permasalahan di antaranya: 1) Metode pembelajaran yang digunakan guru terlalu berorientasi pada aspek teoretis serta materi pembelajaran kurang menyeimbangkan pencapaian kompetensi kognitif, afektif, dan psikomotorik siswa; 2) Belum mampu memanfaatkan potensi sekolah dan mengintegrasikannya pada setiap kompetensi dasar seni musik: 3) Siswa tidak terlatih dalam kreativitas menciptakan karya musik; 4) Siswa lebih

\footnotetext{
Alamat korespondensi: Departemen Pendidikan Musik, Universitas Pendidikan Indonesia Bandung, Jln. Dr. Setiabudhi No.229 Bandung Email: yudi.sukmayadi@upi.edu
} 
bergantung pada alat-alat musik konvensional; 5) Sumber belajar yang masih terbatas.

SMKN 12 Bandung merupakan sekolah yang dilengkapi dengan peralatan pendukung pembelajaran kejuruan termasuk di dalamnya perkakas tangan. Oleh karenanya pembelajaran komposisi musik ini dipandang dapat menjadi model pembelajaran musik yang cukup relevan untuk diterapkan dalam konteks komposisi musik sekolah dengan memanfaatkan peralatan yang ada untuk kepentingan pembelajaran seni musik.

Salah satu kompetensi kejuruan yang harus dicapai oleh siswa adalah keterampilan dalam mengoperasikan perkakas tangan. Sehubungan dengan itu, keterampilan siswa dalam mengoperasikan perkakas tangan pada mata pelajaran produktif kejuruan tersebut dapat diintegrasikan dengan mata pelajaran seni musik khususnya pada materi pokok komposisi musik.

Saat perkakas tangan digunakan oleh siswa, pukulan palu, gesekan gergaji, dan suara lainnya terdengar sebagai bunyi yang khas. Jika aktivitas itu dihubungkan dengan pembelajaran musik, maka bunyi-bunyian yang dihasilkan dari aktivitas siswa pada saat mengoperasikan perkakas tangan dapat dijadikan sebagai bahan utama untuk menciptakan komposisi musik. Hal ini dinilai sebagai langkah yang efektif dan efisien, karena di satu sisi, mengolah bunyi dari perkakas tangan membutuhkan kreativitas tersendiri. Di sisi lain, pemanfaatan perkakas tangan untuk pembelajaran musik menjadi lebih efektif karena memanfaatkan peralatan yang sudah tersedia dan telah dikuasai oleh siswa perihal cara penggunaannya. Pemanfaatan perkakas tangan dalam pembuatan sebuah karya komposisi musik juga dapat menjawab persoalan bahwa pembelajaran komposisi musik dapat dilaksanakan tanpa harus bergantung pada satu jenis alat musik tertentu. Hal ini dianggap penting karena dalam suatu proses pembelajaran musik, setiap medium musik mempunyai keistimewaan penting untuk dikaji dalam rangka proses pengolahan untuk menghasilkan jenis karya musik tertentu (Bintarto, 2014).

Aktivitas siswa dalam menyerap bunyi di sekitar, mengolahnya, dan menggunakan imajinasinya untuk menciptakan bunyi yang lain, kemudian menganalisis hasil dari proses kreatifnya merupakan hal yang mengarah pada pembelajaran musik seutuhnya. Mills (2005: 67) menyebutkan bahwa:

Children frequently focus intently as they experiment with different ways of making sound, different ways of making different sounds. Different ways of assembling sounds into patterns or motifs, and as they try to repeat or re-create sounds, patterns, or motifs that they made earlier. This natural engagement can be drawn into education, and developed through composing, listening, and musical approaches to performing. Instrumental teaching that is no more than repetitive drill or that consists, in effect, of a list of instructions to follow, switches off.

Senada dengan pendapat tersebut, salah satu tujuan diterapkannya model pembelajaran musik berbasis komposisi musik sekolah melalui pemanfaatan perkakas tangan ialah untuk mengembangkan dan membangun keterlibatan intelektual dan imajinasi siswa dalam musik. Keterlibatan intelektual-imajinatif yang datang secara alami berperan sebagai hasil dari proses kreatif siswa. Melalui model pembelajaran ini, instrumen musik dalam seni musik bukan lagi suatu pengulangan latihan dasar yang membuat siswa menjadi tidak aktif atau pasif, melainkan pembelajaran yang seutuhnya mengembangkan kompetensi musikal siswa.

Melalui materi pembelajaran komposisi dalam mata pelajaran seni musik, siswa dapat ditingkatkan apresisasi musiknya, dikembangkan pengetahuannya, dan dibangun keterampilannya dalam berkreasi. Apresiasi dalam kegiatan pembelajaran komposisi musik merupakan proses mengidentifikasi, menyerap, dan memahami substansi dari sebuah karya komposisi musik berdasarkan dari karya musik yang telah ada. Kegiatan ini pun dapat dijadikan sebagai salah satu upaya bagi siswa untuk menemukan inspirasi, ide, dan gagasan sebagai bahan dasar untuk penciptaaan karya.

Berkaitan dengan pembelajaran komposisi musik yang memiliki kedudukan penting dalam pendidikan seni di sekolah dinyatakan oleh Swanwick (1999: 55) bahwa: 
Composing is thus an educational necessity, not some optional activity when time permits. It gives students an opportunity to bring their own ideas to the micro-culture of the classroom, infusing formal education with music from 'out there'. Teachers then become aware not only of the musical pathways of students but also to some extent of their social and personal worlds.

Perancangan model pembelajaran berbasis komposisi musik sekolah ini diselaraskan dengan materi seni musik yang semestinya disampaikan dalam pembelajaran seni budaya sesuai dengan Kurikulum Tingkat Satuan Pendidikan. Materi yang diajarkan dalam model pembelajaran ini dimulai dari apresiasi melalui beragam repertoar komposisi musik, kemudian pemberian materi dasar komposisi musik untuk meningkatkan pengetahuan dan menambah wawasan siswa, sampai pada akhirnya siswa dapat memainkan, menampilkan, dan menganalisis hasil karya dari komposisi musiknya sendiri. Model pembelajaran musik yang dibuat merujuk konsep pembelajaran seni yang mengarah pada aspek psikologis, potensi musikal dan perkembangan para siswa, serta memerhatikan aspek kompetensi dalam pembelajaran seni musik.

\section{Rancangan dan Pengembangan Model Pembelajaran}

Permainan musik dengan menggunakan alat musik non-konvensional dalam beberapa literatur disebut dengan musik eksperimental. Salah satu tokoh yang paling berpengaruh dalam perkembangan jenis musik ini ialah John Cage (1912-1992). John Cage merupakan sosok yang membawa pandangan baru dalam dunia musik terutama berkaitan dengan alat musik yang dimainkan. Mack (2004: 104) mengungkapkan bahwa yang paling "aneh" dalam musik eksperimental John Cage adalah peralatannya. Peralatan untuk karyanya ada yang menggunakan lembaran seng dan rem besi. Hal itu berdasar pada konsep dari musik eksperimental John Cage yang mengutamakan segala hal yang bisa berbunyi secara unik.
Berdasarkan pernyataan Mack (2004) tersebut, dalam permainan musik, terutama dalam pembelajaran komposisi musik, penggunaan alat tidak selalu harus menggunakan alat musik konvensional. Terutama persoalan alat tersebut menjadi faktor penghambat dalam proses pembelajaran musik di sekolah. Paynter dan Aston (1970: 341) menyatakan bahwa:

Experimental Music in Schoolsconsists of a series of graduated exercises. At first students listen to the sounds around them and put together little "pieces" out of these sounds. They then add simple percussion instruments, learn new notational systems, make larger pieces, and finally reach electric nirvanawhere they record their efforts at one speed, chop them up and play them back at another.

Beberapa pendapat di atas mengukuhkan bahwa melalui komposisi musik perkakas tangan (baca: alat musik non konvensional) menawarkan inovasi pembelajaran yang dapat mewadahi pencapaian berbagai kompetensi musikal, mengatasi persoalan keterbatasan media pembelajaran (alat musik), sekaligus sebagai model pembelajaran yang mampu mengangkat keunikan dari sekolah kejuruan itu sendiri. Model pembelajaran yang diterapkan mengarah pada tahap kemandirian siswa, keterlibatan siswa secara bertahap semakin ditingkatkan. Adapun alur pengembangan kreativitas siswa melalui model pembelajaran komposisi musik melalui pemanfaatan media perkakas tangan ini mengadapatasi proses penciptaan karya yang dilakukan oleh Suneko, ketika proses perwujudan karya yang berjudul Pyang Pyung, di mana tahapan pengolahan karyanya melalui serangkaian proses yang terdiri dari empat tahapan yakni: eksplorasi, eksperimentasi, aplikasi, dan tahap penyajian (Suneko, 2016). Adaptasi proses semacam ini diwujudkan sebagaimana dalam tahapan berikut.

\section{Tahapan Pra Siklus/Input}

Tahap perancangan model pembelajaran secara garis besar dibagi menjadi tiga kajian utama, yaitu: Pertama, menganalisis materi pembelajaran komposisi musik yang sesuai dengan subjek penelitian. Kedua, menganalisis dan mengolah media perkakas tangan yang akan 
dijadikan alat musik non-konvensional sebagai media pembelajaran. Ketiga, menyusun beberapa komponen pembelajaran seni musik untuk jenjang sekolah menengah kejuruan. Analisis dan penyesuaian komponen pembelajaran perlu mendapat perhatian khusus agar tujuan dari penerapan model ini dapat tercapai sesuai dengan yang diharapkan.

\section{Siklus Proses Kreatif}

Siklus proses kreatif yaitu kegiatan pembelajaran yang berkaitan dengan proses kreatif komposisi musik perkakas tangan. Pada siklus ini terdapat tiga siklus dalam empat tahap sesuai dengan konsep model yang dibuat.

\section{a. Tahap Pengenalan}

Kegiatan belajar terdiri atas mengapresiasi dan menganalisis musik komposisi nonkonvensional. Kompetensi yang dapat dicapai oleh siswa di antaranya: kemampuan dalam memahami materi berkaitan dengan komposisi musik dan alat musik nonkonvensional, dan kemampuan dalam menganalisis unsur musik yang terdapat dalam rekaman video pertunjukan musik komposisi yang diapresiasi.

Secara keseluruhan, pembelajaran yang diimplementasikan pada tahap pengenalan dibagi menjadi dua kegiatan inti yang terdiri dari: (1) kegiatan pembelajaran apresiasi musik, menyimak dan mengamati rekaman video reportoar pertunjukan komposisi musik yang menggunakan alat-alat musik non-konvensional, dan (2) kegiatan diskusi kelompok dalam menganalisis karya komposisi musik yang telah diapresiasi, dan diskusi kelompok dalam menentukan ide awal komposisi yang akan dilaksanakan pada pertemuan berikutnya.

Komposisi yang disajikan dalam kegiatan belajar apresiasi ini, terutama karya komposisi yang spesifik memainkan musik dengan menggunakan media yang berbeda pada setiap reportoar komposisi yang ditayangkan. Hal ini dilakukan agar membuka pikiran siswa bahwa dalam menciptakan karya komposisi dapat dengan menggunakan alat musik non- konvensional, salah satunya menggunakan perkakas tangan.

\section{b. Tahap Pendalaman}

Kegiatan belajar siswa pada tahap ini adalah mengeksplorasi perkakas tangan menjadi media bunyi dalam komposisi yang dibuat. Salah satu kompetensi utama pada tahap ini adalah keterampilan siswa dalam mengolah beragam variasi teknik penggunaan perkakas tangan dan pengolahan unsur warna bunyi melalui kegiatan eksperimen. Kegiatan ini diawali dengan mengidentifikasi dan menggolongkan perkakas tangan berdasarkan karakter warna bunyi yang dihasilkannya dan penggolongan perkakas tangan berdasarkan berbagai variasi teknik penggunaan perkakas tangan. Agar siswa dapat memiliki kecakapan dalam mengolah perkakas tangan menjadi alat musik, maka siswa perlu untuk melakukan eksplorasi terhadap perkakas tangan yang akan digunakan untuk membuat komposisi musiknya itu.

Keterampilan siswa dalam memilih dan mengelola perkakas tangan yang dipakai dan yang dibutuhkan dalam komposisi musiknya tidak terlepas pada kemampuannya dalam mengimajinasikan hubungan antara warna bunyi yang dihasilkan oleh perkakas tangan yang satu dengan warna bunyi perkakas tangan lainnya. Hal tersebut merupakan salah satu hal penting dalam konteks pembelajaran seni, karena hasil karya seseorang dalam menciptakan komposisi musik sangat bergantung pada kemampuan imajinatif setiap individu. Kaschub dan Smith (2009) mengungkapkan bahwa pencarian bunyi dapat berguna dalam komposisi yang sedang dibuat, langkah pencarian ide musikal dalam pembuatan karya komposisi. Melalui kegiatan eksperimen terhadap perkakas tangan dalam model komposisi musik siswa dilatih kemampuan kreatifnya agar dapat menemukan ide komposisi musik melalui eksplorasi bunyi. Bunyi ini dieksplorasi dan disusun dalam suatu bentuk sederhana yang memungkinkan adanya proses pengembangan dan pengolahan imajinasi, kreasi, dan intuisi siswa. 
Berbagai macam perkakas tangan yang dieksplorasi dan digunakan oleh siswa berguna sebagai alat musik non-konvensional sekaligus sebagai media kreatif penyusunan komposisi musik. Perkakas tangan tersebut diantaranya: kunci pas (Open end wrench), kunci kombinasi (Combination wrench), obeng (Screw driver), kunci ring (box wrench), kunci soket (Socket wrench) Ratchet handle, Gergaji Tangan (Hacksaw), palu karet (lunak), dan penggaris besi. Berikut ini penjelasan dengan beberapa gambar dari perkakas tangan tersebut.

Pada gambar 1 terlihat kedua tangan siswa sedang memegang kunci pas sebagai media bunyi dengan teknik memainkan secara dipukul untuk mengeksplorasi warna bunyi dari perkakas tersebut. Penggunaan variasi ukuran dari kunci pas bertujuan untuk mengolah perbedaan pitch level yang dihasilkan oleh perkakas tersebut.

Perbedaan ukuran pada setiap perkakas dengan maksud agar pada saat dibunyikan dapat mengasilkan frekuensi bunyi yang berbeda pula, semakin besar nomor dan ukuran perkakas tangan yang dibunyikan (kunci pas, kunci ring, dan kunci kombinasi) maka semakin rendah frekuensi bunyi yang dihasilkan, dan begitu pula dengan kunci pas yang berukuran lebih kecil akan menghasilkan frekuensi yang lebih tinggi. Berikut ini penggalan dari notasi motif melodi yang telah dibuat oleh siswa melalui penggunaan perkakas tangan berdasarkan interpretasi siswa.

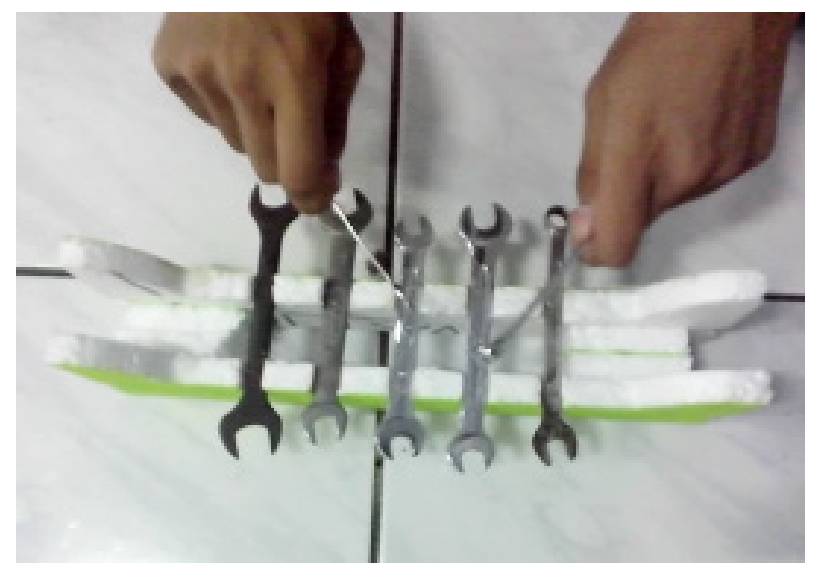

Gambar 1. Teknik memainkan perkakas tangan kunci pas dan kunci kombinasi.
Pada gambar 2, kedua tangan siswa sedang memegang obeng sebagai pemukul dan perkakas tangan kunci pas, kunci ring sebagai alat media penghasil bunyi atau sumber bunyi. Siswa mengeksplorasi beberapa jenis perkakas tangan tersebut untuk warna bunyi dalam menerapkan sistem harmoni pada alat musik yang digunakannya.

Pada gambar 3, siswa sedang memegang obeng dan kunci ring sebagai media bunyi untuk mengeksplorasi warna bunyi yang dihasilkan oleh perkakas tangan tersebut. Penggunaan variasi ukuran dari kunci ring berfungsi sebagai sumber bunyi untuk mengolah perbedaan pitch level, dan penggunaan obeng berfungsi sebagai media penghasil bunyi (pemukul).

Pada gambar 4, siswa melakukan eksplorasi perkakas tangan. Pada gambar tersebut, tangan kanan siswa sedang memegang kunci pas media penghasil bunyi, dan kunci soket sebagai sumber bunyi dengan teknik penggunaan menggesekan kedua perkakas tersebut untuk mengeksplorasi warna bunyi yang diproduksi oleh kedua perkakas tersebut. Pada kegiatan eksperimen ini, siswa melakukan percobaan terhadap kedua perkakas tangan untuk menemukan efek noise.

Pada gambar 5 , siswa sedang melakukan eksplorasi perkakas tangan. Pada gambar tersebut, terlihat tangan kanan siswa sedang memegang obeng media penghasil bunyi dan tangan kiri memegang gergaji sebagai

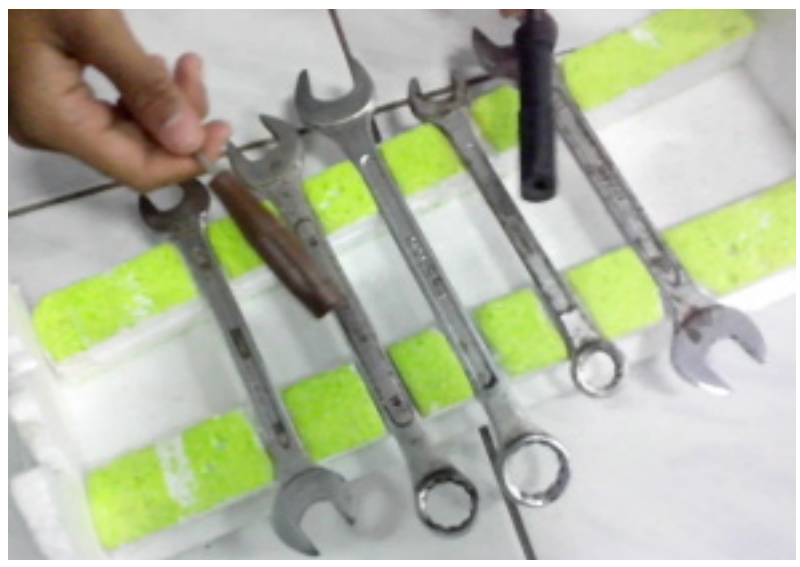

Gambar 2. Teknik memainkan perkakas tangan obeng, kunci pas, dan kunci kombinasi. 
sumber bunyinya. Teknik yang digunakan untuk mengolah bunyi pada kedua perkakas tersebut ialah dengan cara menggesekan obeng pada bagian gerigi yang terdapat pada gergaji tangan. Melalui penggunaan kedua perkakas tersebut, siswa dapat mengolah bunyi untuk memproduksi bunyi noise, atau warna bunyi yang memiliki karakter tajam dan kasar. Siswa sudah memiliki keterampilan khusus dalam mengoperasikan perkakas tangan terbut dalam kegiatan kerja bengkel. Oleh sebab itu, siswa dapat mengidentifikasi teknik penggunaan yang paling tepat untuk menghasilkan jenis bunyi yang diinginkan dengan prosedur pengoperasian yang aman.

Pada gambar 6, siswa sedang melakukan eksplorasi perkakas tangan: tangan kanan siswa sedang memegang obeng sebagai yang dipukulkan pada penggaris besi dan tutup kaleng bekas, dan tangan kiri siswa sedang memegang palu karet yang dipukulkan pada kotak kayu yang dilapisi oleh styrofoam. Penggunaan perkakas tangan tersebut untuk mengeksplorasi variasi pola ritmis yang diadaptasi dari alat musik perkusi drum.

Pada tahap pendalaman, selain kegiatan siswa berupa penggolongan dan pengorganisasian perkakas tangan, pada kegiatan pembelajaran ini siswa juga melakukan percobaan mengenai teknik penggunaan perkakas tangan yang beralih fungsi menjadi sebuah alat musik, sehingga prosedur penggunaan berbeda dengan teknik penggunaan perkakas tangan sebagai peralatan

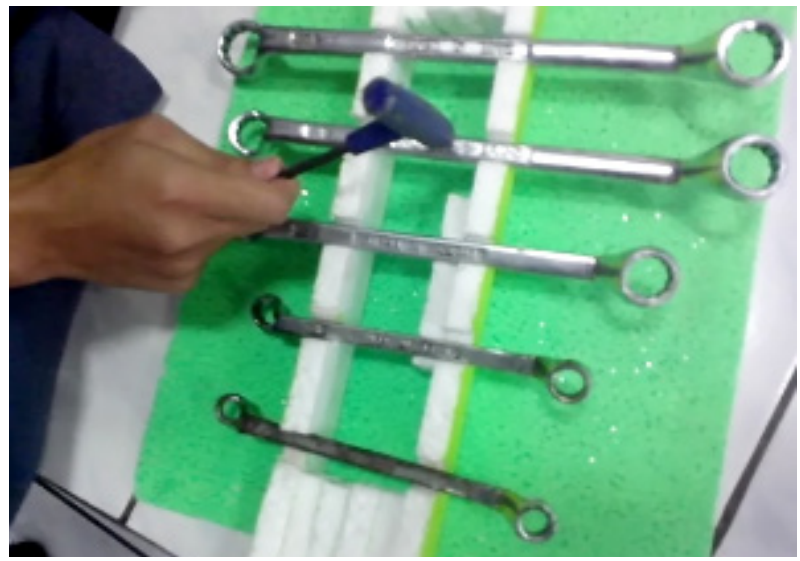

Gambar 3. Teknik memainkan perkakas tangan kunci ring dan obeng " $\mathrm{T}$ ".

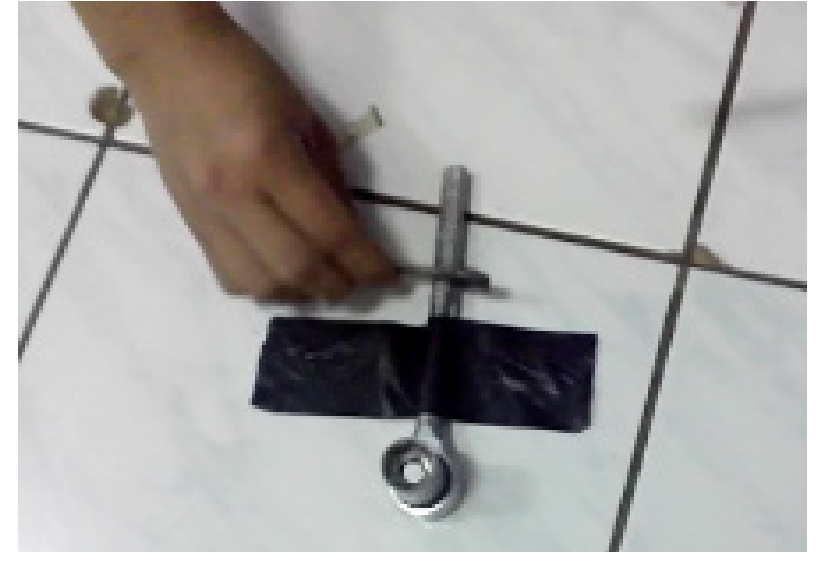

Gambar 4. Teknik memainkan perkakas tangan kunci pas dan kunci soket.

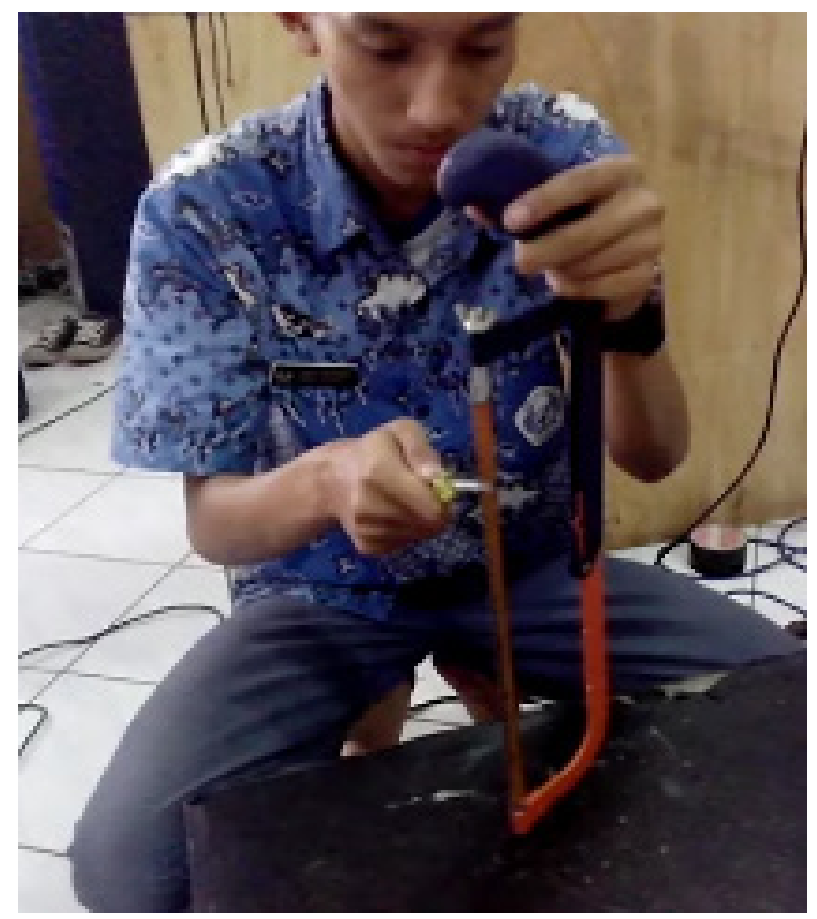

Gambar 5. Siswa sedang mengeksplorasi perkakas tangan obeng dan gergaji tangan.

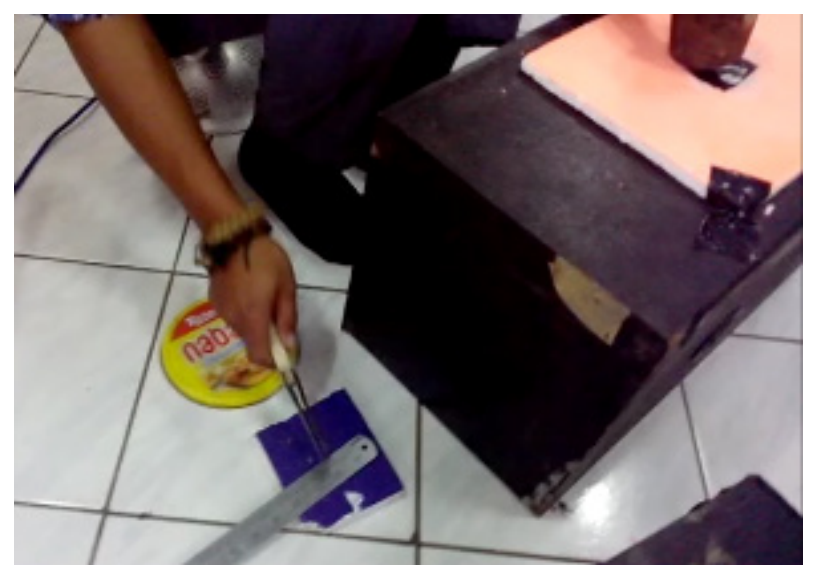

Gambar 6. Teknik memainkan perkakas tangan palu karet, obeng, dan penggaris besi. 
kerja dalam bengkel, dengan demikian teknik menggunakan perkakas tangan berubah menjadi teknik memainkan perkakas tangan.

Pada saat melakukan eksperimen dalam kegiatan eksplorasi ini, siswa menemukan berbagai cara untuk memodifikasi perkakas tangan agar bunyi yang dihasilkan oleh perkakas tangan tersebut sesuai dengan kebutuhan komposisi musiknya. selain itu, modifikasi yang dilakukan agar kemudian perkakas tangan dapat dimainkan secara baik sehingga siswa menambahkan beberapa bagian sebagai penyangga perkakas tangan tersebut. Peningkatan kemampuan berpikir

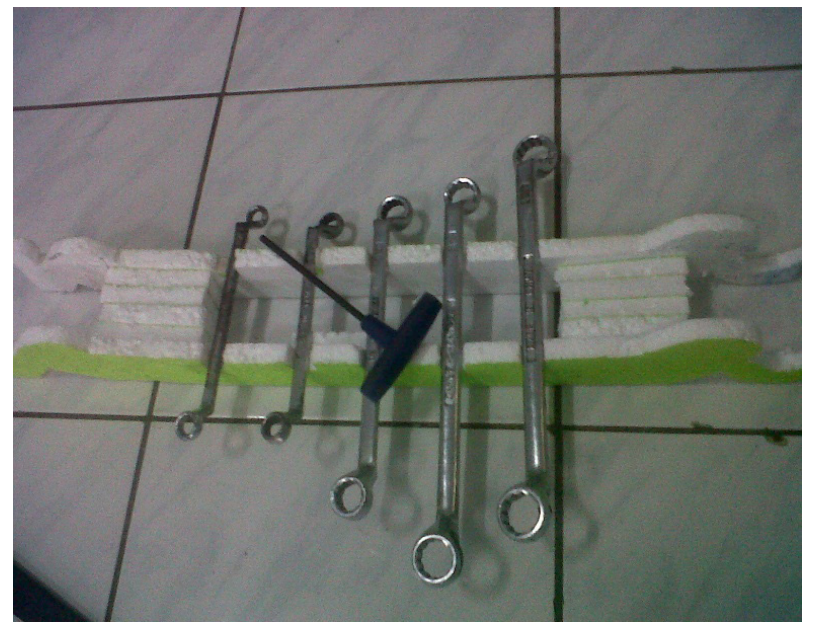

Gambar 7. Perkakas tangan kunci ring kelompok A yang telah dimodifikasi.

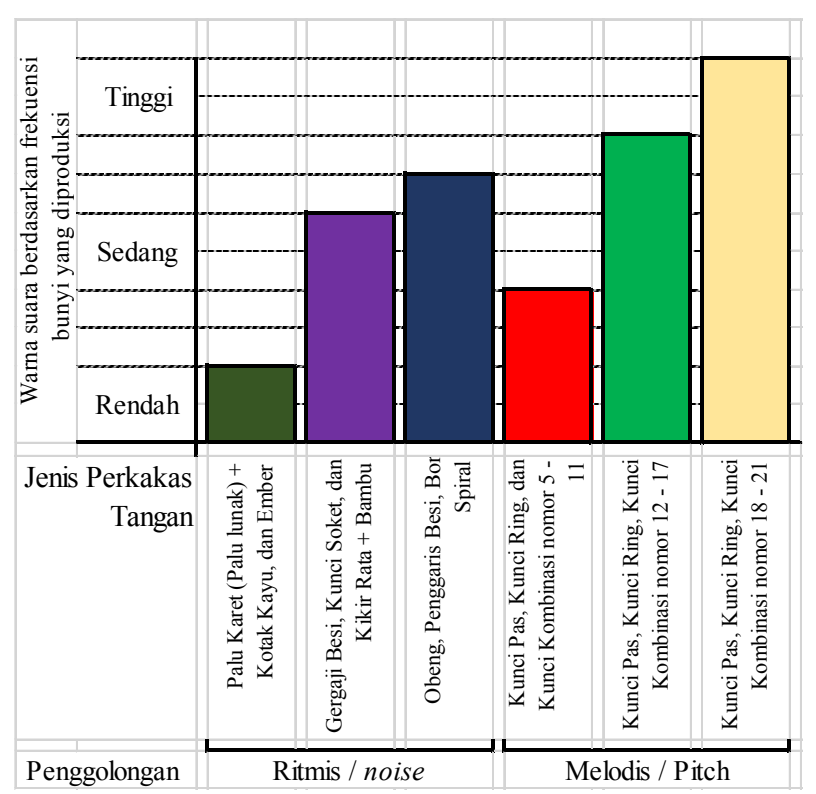

Gambar 8. Pengelompokan perkakas tangan berdasarkan warna bunyi dan fungsinya dalam komposisi musik. siswa ditunjukan oleh hasil eksperimen dalam kegiatan pembelajaran eksplorasi ini. Gambar 7 menunjukkan modifikasi perkakas tangan yang dilakukan oleh siswa sebagai hasil kreatif dalam kegiatan eksperimen.

Gambar 7 merupakan hasil modifikasi perkakas tangan yang dilakukan oleh siswa. Modifikasi yang dimaksud bukan dalam pengertian mengubah konstruksi perkakas tangan melainkan hanya menambahkan styrofoam atau polistirena sebagai penyangga dari perkakas tangan yang digunakan agar bunyi yang dihasilkan lebih optimal, dengan demikian sustain dari perkakas tersebut tidak teredam secara cepat. Selain itu, sesuai dengan fungsinya sebagai penyangga adalah agar perkakas tangan tidak berubah posisi pada saat dibunyikan sehingga dapat dimainkan secara lebih mudah. Hal tersebut dapat dikatakan sebagai inovasi kreatif dan produktif yang dilakukan oleh siswa, sebagai salah satu tujuan dari pembelajaran komposisi musik perkakas tangan.

Setelah siswa dapat menganalisis, mengelompokkan, memodifikasi, dan mencoba membunyikan perkakas tangan tersebut, siswa dapat mulai mengolah bunyi perkakas tangan melalui permainan musik sederhana dalam bentuk pola ritmis yang pendek pada salah satu perkakas tangan dan selanjutnya membuat pola yang lain dengan pola ritmis yang berbeda. Kegiatan tersebut merupakan tahap mengimplementasikan ide komposisi musik, sekaligus menyusun struktur awal dari komposisi yang dibuat.

\section{c. Tahap Pengembangan}

Pada tahap ini, kegiatan siswa tidak lagi fokus pada ekplorasi bunyi dari perkakas tangan, namun siswa didorong mencipta komposisi sederhana yang mengolah unsur-unsur musik diantaranya; tempo, dinamika, pola ritmis, dan timbre. Pada tahap pengembangan ini, siswa diberikan kesempatan untuk menyusun melodi pendek dalam komposisinya. Salah satu perbandingan siswa dapat dikenalkan tentang konsep yang dikembangkan oleh Jatmika (2016) bahwa 
dalam penyusunan melodic pattern dan cara penggunaan akor yang dijadikan landasan dalam menyusun motif atau tema musik yang dikembangkan menggunakan prosedur dasar pengembangan komposisi seperti inversi, retrogresi, augmentasi, dan diminusi.

Aktivitas inti lainnya pada kegiatan pembelajaran pengembangan komposisi musik perkakas tangan yaitu pembuatan partitur grafis sebagai interpretasi visual siswa terhadap komposisi bunyi perkakas tangan yang dirancang ke dalam simbol tertentu.

1. Penerapan Unsur-unsur Musik dalam

Komposisi Perkakas Tangan.

Aktivitas belajar siswa pada tahap ini adalah mengembangkan kreativitas dalam menerapkan unsur-unsur musik dalam permainan komposisi melalui penggunaan perkakas tangan. Penerapan unsur musik yang dapat diolah dan diterapkan pada komposisi musik perkakas tangan di antaranya:

a) Siswa mampu menerapkan dinamika pada saat memainkan perkakas tangan dalam komposisi musik yang dibuatnya. Siswa dapat mengetahui cara mengatur tenaga/kekuatan ketika memainkan perkakas tangan sehingga keras lembutnya volume bunyi yang dihasilkan berbeda-beda, dengan demikian dinamika sebagai salah satu unsur musik dapat dipahami sekaligus diterapkan dalam permainan musik.

b) Siswa dapat mengatur cepat atau lambatnya pola ritmik yang telah dibuat sehingga konsep dari tempo yang berhubungan dengan cepat lambatnya suatu permainan musik dapat dipahami sekaligus diterapkan pada saat yang sama.

c) Siswa dapat mengidentifikasi dan mengolah perbedaan warna bunyi (timbre) dari sebuah perkakas tangan melalui teknik penggunaan perkakas tangan yang berbeda dan bervariasi.

d) Siswa dapat mengenali dan menerapkan unsur "Pitch level" melalui teknik permainan dan penggunaan perkakas tangan yang berbeda ukuran. Pitch level yang dimaksud dapat dihasilkan oleh perkakas tangan yang sejenis namun memiliki variasi ukuran yang berbeda, contohnya: kunci pas dan kunci ring memiliki ukuran yang terkecil yakni nomor 6 sampai dengan yang terbesar yaitu nomor 24. Semakin kecil nomor dari perkakas tersebut, akan menghasilkan frekuensi yang lebih tinggi, begitu pula sebaliknya, semakin besar ukuran dan nomor perkakas tersebut, akan semakin rendah warna bunyi yang dihasilkan. Ini disebabkan semakin tebal benda atau plat, semakin tinggi frekuensi yang dihasilkan. Hal ini bisa dibandingkan dengan salah satu instrument gamelan, saron misalnya. Semakin tipis semakin rendah, sebaliknya semakin tebal, frekuensinya semakin tinggi (Prasetya, 2013).

2. Penulisan Partitur Grafis

Partitur grafis yang dimaksud adalah menuliskan simbol-simbol bunyi berkenaan dengan ide dan tema komposisi. Hal itu diterapkan sebagai adaptasi dari teori yang digagas oleh Kodaly. Salah satu sistem pembelajaran musik yang dikembangkan oleh Kodaly yaitu suatu sistem pembelajaran musik yang bertujuan

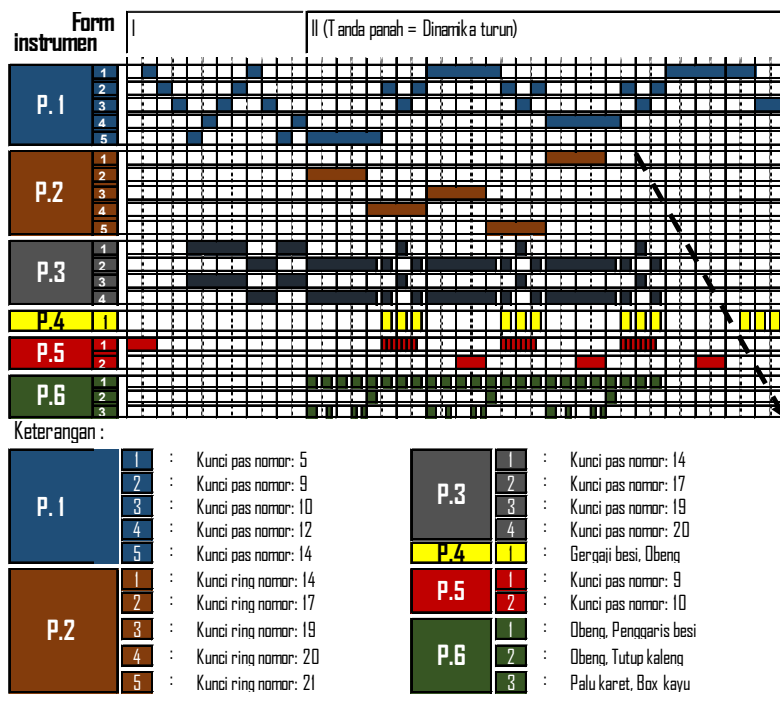

Gambar 9. Partitur grafis komposisi musik Perkakas Tangan. 
untuk mengembangkan musical literacy yakni kemampuan untuk berpikir, membaca, menulis, dan berkreativitas melalui simbol musik.

Partitur grafis yang dibuat oleh siswa tersebut merupakan hasil adaptasi dari beberapa format penulisan partitur grafis dalam komposisi musik, di antaranya: 1) teknik penulisan partitur grafis "Tetabuhan Sungut" karya Slamet Abdul Syukur, dan 2) teknik penulisan musik digital dalam softwarefruityloop.

Dalam mentransformasikan bunyi dalam bentuk simbol visual siswa menggunakan aplikasi program komputer. Aplikasi software yang digunakan oleh siswa untuk memudahkan penulisan partitur grafis tersebut adalah program Microsoft Excel 2013. Berikut gambar yang menjelaskan teknik penulisan dan cara membaca partitur tersebut.

1. Layer untuk menunjukkan jumlah pemain musik dalam komposisi musiknya. misalnya, dari partitur grafis pada gambar dapat dilihat bahwa partitur tersebut terdapat 6 layer, masing-masing memiliki warna dan penamaan yang berbeda. Artinya dalam kelompok A terdapat 6 orang siswa yang memainkan komposisi musiknya yang ditandai dengan P.1, P.2, P.3, P.4, P.5.

2. Garis vertikal, yang berfungsi menandakan ketukan dasar dan nilai not dari bunyi yang dimainkan oleh perkakas tangan. Garis vertikal tebal menandakan ketukan tesis/on-beat, sedangkan garis vertikal yang terputus-putus menandakan arsis/up-beat.

3. Kolom yang berwarna bukan putih (berwarna biru, coklat, kuning, dst) menunjukkan perkakas dibunyikan, sedangkan kolom berwarna putih menandakan perkakas berhenti atau tidak dibunyikan. Jarak antara garis tebal dengan garis setelahnya adalah satu ketuk atau memiliki nilai not $1 / 4$, sedangkan jarak antara garis tebal dengan garis putus-putus adalah setengah ketuk atau memiliki nilai not $1 / 8$ ketuk. Dengan demikian nilai not atau durasi bunyi dari perkakas tangan yang dibunyikan dapat diketahui melalui kualitas warna yang terdapat pada partitur tersebut.

4. Garis dan kolom horisontal berfungsi untuk menunjukan Pitch level atau frekuensi tinggi rendahnya warna bunyi yang dihasilkan oleh sebuah perkakas tangan. Warna biru pada kolom yang terletak dibagian atas menandakan bunyi dari perkakas tangan yang dibunyikan memiliki pitch level yang tinggi, dan sebaliknya warna biru pada kolom yang terletak pada bagian bawah menunjukan bunyi dari perkakas tangan yang dibunyikan memiliki pitch level yang rendah. selain itu, kolom dalam garis horizontal juga dapat berfungsi untuk menandakan timbre dari perkakas yang digunakan, dengan demikian dapat diketahui berapa jumlah perkakas yang dimainkan oleh seorang siswa.

Sebagai bagian paling akhir dari rangkaian proses di atas, siswa melakukan revisi, baik ketika proses latihan berlangsung maupun setiap selesai latihan. Hasil bunyi dari notasi yang telah disusun kadang tidak sesuai dengan harapan yang ada dalam imajinasi. Proses revisi sangat memengaruhi terhadap elemen karya yang akan diwujudkan. Revisi mencakup berbagai hal diantaranya: penulisan notasi, nada, irama/tempo, pengulangan (repetisi), dinamika bunyi (keras atau lirih, pelan dalam konteks volume), dan teknik membunyikan maupun yang berkaitan dengan vocal (Karbito, 2015).

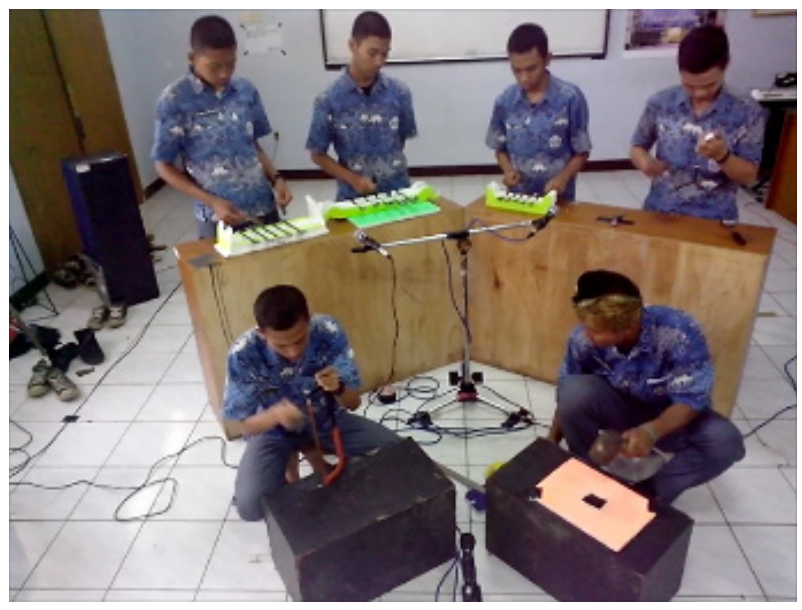

Gambar 10. Penampilan komposisi musik perkakas tangan 


\section{d. Tahap Penampilan}

Pada tahap penampilan siswa menampilkan hasil kreasinya dalam membuat komposisi. Pengalaman musikal melalui penampilan ini merupakan salah satu hal penting pada proses pembelajaran untuk menumbuhkan pribadi percaya diri, kreatif dan produktif.

Kemampuan setiap siswa dalam menampilkan komposisi musik perkakas tangan membuktikan bahwa setiap orang mempunyai potensi musikal yang hampir sama dan merata. Potensi tersebut dapat ditumbuhkembangkan selama siswa diberi kesempatan untuk mendapatkan pembelajaran seni yang berorientasi pada pencapaian kompetensi sikap, pengetahuan, dan keterampilan musikal siswa.

\section{Penerapan Model Pembelajaran}

Model pembelajaran musik berbasis komposisi musik melalui pemanfaatan perkakas tangan yang dikembangkan di SMKN 12 Bandung merupakan bagian dari pendidikan formal bagi siswa dalam pendidikan seni. Hal ini secara umum bertujuan meningkatkan pengetahuan, keterampilan, dan sikap percaya diri, tanggung jawab, kreatif, mandiri, dan memiliki harga diri, serta memiliki jiwa optimis sebagai anak yang bermakna bagi dirinya sendiri, keluarga, dan yang pada akhirnya dapat membekali para siswa kelak dalam kehidupan masyarakat untuk menjadi individu yang bermanfaat, kreatif, dan produktif.

Tahapan pembelajaran yang terdapat pada model pembelajaran komposisi musik perkakas tangan terdiri dari:(1) Tahap Pengenalan; Apresiasi,

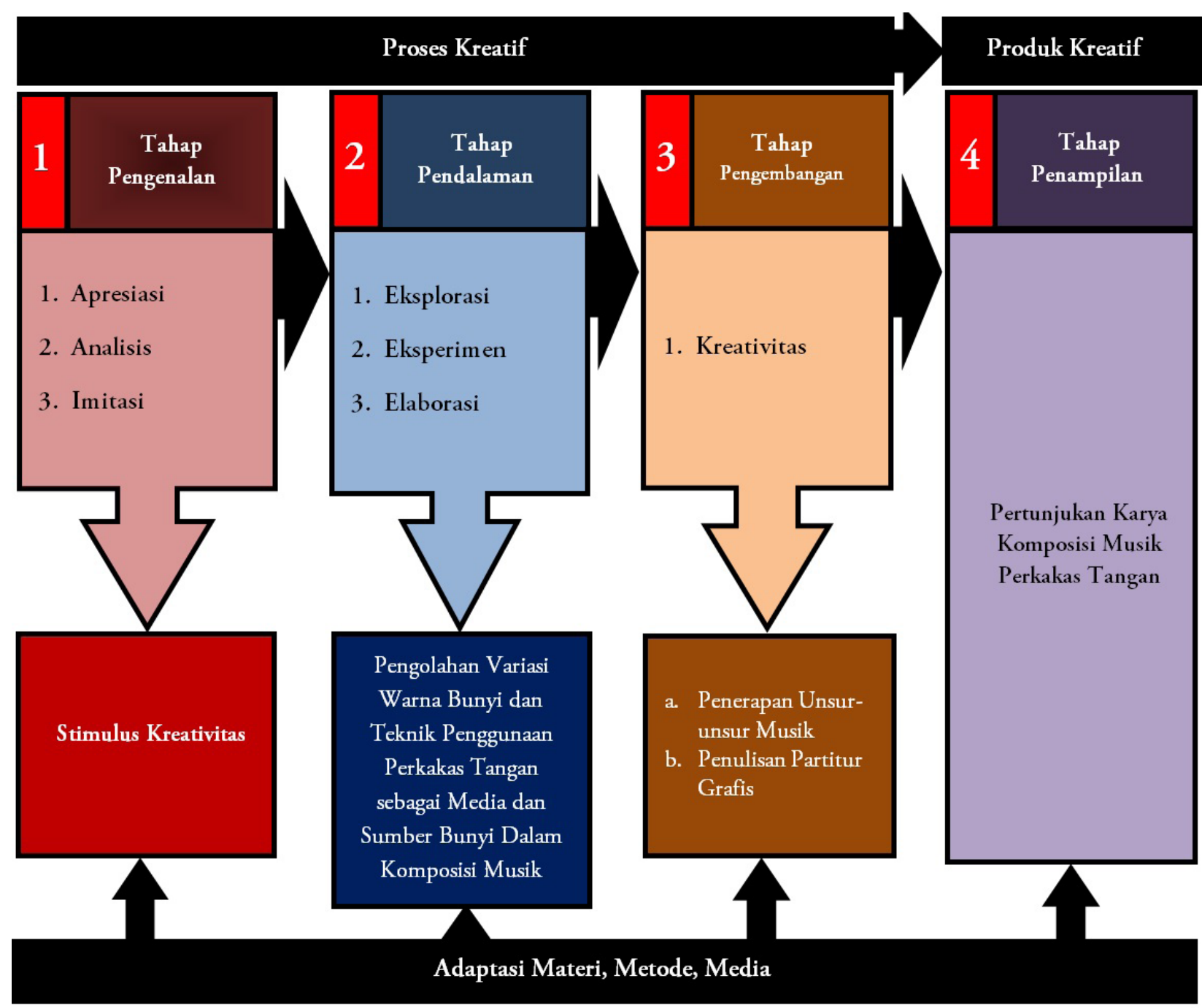

Gambar 11. Bagan model pembelajaran dengan tahapan alur dan materi. 
Analisis, Imitasi, (2) Tahap Pendalaman; Eksplorasi, Eksperimen, Elaborasi, (3). Tahap Pengembangan; Kreativitas, (4). Tahap Penampilan; Pertunjukan karya sebagai produk kreatif.

\section{Indikator Keberhasilan Model}

Keberhasilan suatu program pengembangan model pembelajaran komposisi musik dengan memanfaatkan perkakas tangan di SMKN 12 Bandung dapat dilihat dari hasil monitoring evaluasi berikut.

1. Sebagian besar siswa memberi respon yang positif dalam mengikuti proses pembelajaran. Hal tersebut ditunjukan melalui pengamatan sikap siswa selama kegiatan pembelajaran pada setiap tahap dalam model pembelajaran komposisi musik perkakas tangan.

2. Model pembelajaran yang dilaksanakan dan dibahas bersama, dapat dirasakan manfaatnya untuk peningkatan kreativitas, perubahan sikap, dan keterampilan yang produktif.

3. Selama kegiatan pembelajaran berlangsung, semua siswa dapat mengikutinya sampai dengan selesai, dalam arti tidak ada siswa yang mengundurkan diri atau tidak tuntas dalam melaksanakan kegiatan pembelajaran.

4. Seluruh siswa dapat mencapai kompetensi yang diharapkan pada setiap tahap pembelajaran

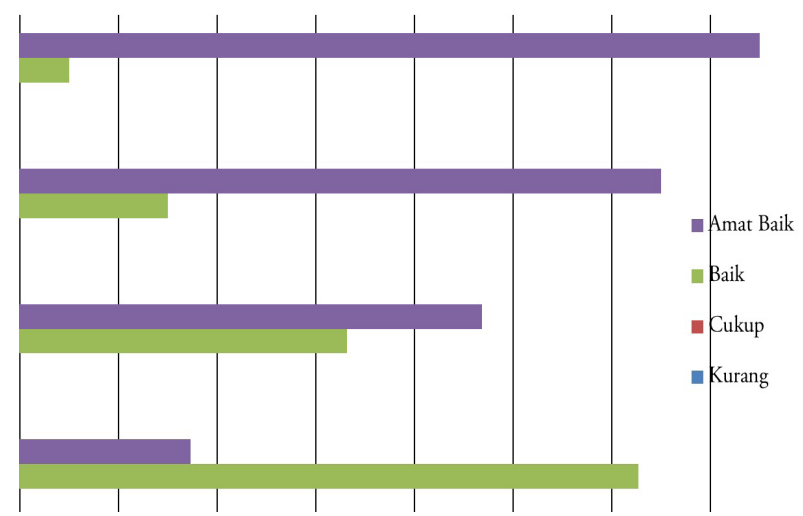

Gambar 12. Grafik peningkatan kompetensi musikal siswa. dengan kategori nilai minimal baik. Pencapaian prestasi hasil belajar tersebut dapat dilihat pada tabel 1.

Berdasarkan tabel 1 disimpulkan bahwa kemampuan siswa pada setiap tahap pembelajaran cenderung mengalami peningkatan. Gambar 12 menunjukkan grafik peningkatan prestasi siswa.

\section{Penutup}

Secara umum, penelitian ini telah mencapai tujuannya yakni mendeskripsikan rancangan, efektivitas, dan mengimplementasikan model pembelajaran komposisi musik berbasis komposisi musik sekolah melalui pemanfaatan perkakas tangan sebagai media kreatif di SMKN 12 Bandung. Model ini diterapkan berdasarkan pertimbangan bahwa pada dasarnya setiap siswa Sekolah Menengah Kejuruan (SMK) memiliki potensi yang unggul dan berkembang dalam bidang seni musik terutama dalam membuat dan menampilkan karya komposisi musik melalui penggunaan alatalat musik non-konvensional perkakas tangan sepanjang ada lembaga pendidikan/sekolah yang memfasilitasi sistem pembelajaran kreatif dan produktif secara berkesinambungan. Secara khusus penelitian ini mengajukan kesimpulan-kesimpulan sebagai berikut :

Pertama, pembelajaran yang dilakukan oleh guru dalam pembelajaran seni musik di SMKN 12 Bandung bertujuan untuk memberikan pembelajaran kepada siswa di sekolah melalui pengalaman berapresiasi, berekspresi dan pengalaman bermusik yang didapatnya, sehingga tumbuh kepekaan rasa terhadap kesenian, serta dapat menghargai seni dan budaya. Namun kemampuan untuk menuju ke arah tersebut tidak mudah, karena pembelajaran musik kadang terkendala dengan ketersediaan sarana dan pra-sarana pembelajaran. Oleh karena itu, pembelajaran yang memanfaatkan perkakas

\begin{tabular}{|c|c|c|c|c|c|c|c|c|c|c|c|c|c|c|c|c|}
\hline $\begin{array}{l}\text { Tahap } \\
\text { Pembelajaran }\end{array}$ & \multicolumn{4}{|c|}{ Tahap Pengenalan } & \multicolumn{4}{|c|}{ Tahap Pendalaman } & \multicolumn{4}{|c|}{ Tahap Pengembangan } & \multicolumn{4}{|c|}{ Tahap Penampilan } \\
\hline Kriteria & Kurang & Cukup & Baik & $\begin{array}{c}\text { Amat } \\
\text { Baik }\end{array}$ & Kurang & Cukup & Baik & $\begin{array}{c}\text { Amat } \\
\text { Baik }\end{array}$ & Kurang & Cukup & Baik & $\begin{array}{c}\text { Amat } \\
\text { Baik }\end{array}$ & Kurang & Cukup & Baik & $\begin{array}{c}\text { Amat } \\
\text { Baik }\end{array}$ \\
\hline Persentase & 0,00 & 0,00 & 72,73 & 27,27 & 0,00 & 0,00 & 43,18 & 56,82 & 0,00 & 0,00 & 25,00 & 75,00 & 0,00 & 0,00 & 15,00 & 85,00 \\
\hline
\end{tabular}

Tabel 1. Rekapitulasi pencapaian kompetensi belajar setiap tahap pembelajaran. 
tangan sebagai media kreatif dapat menjadi model pembelajaran yang berorientasi pada pencapaian kompetensi musikal siswa dan mendayagunakan keunikan yang dimiliki oleh sekolah kejuruan.

Kedua, model diawali dengan pertimbangan kondisi objektif para siswa. Proses pembelajaran dipadukan dengan bimbingan dan latihan dari guru, melalui berbagai strategi terutama dengan menumbuhkembangkan keterampilan para siswa di dalam setiap kesempatan. Hasil adaptasi model dianalisis secara deskriptif untuk membuat keputusan dalam memperbaiki konseptual model yang telah dibuat untuk siap diujicobakan, cara mengimplementasikan model diawali dengan proses identifikasi kebutuhan belajar siswa, selanjutnya disiapkan model pembelajaran kreatif dan produktif dalam empat tahap.

Ketiga, penilaian dilakukan secara deskriptif melalui pengamatan, wawancara, dan eksperimen. Hasil analisis data menunjukkan bahwa terdapat peningkatan dan pengembangan kreativitas siswa melalui berbagai pembelajaran. Selanjutnya model yang sudah dilaksanakan dikembangkan berdasarkan kebutuhan dan kemampuan siswa, selain terjadi pengembangan kreativitas siswa, juga terdapat perubahan yang sangat mendasar dimana siswa memiliki rasa tanggung jawab yang sangat tinggi, memiliki rasa percaya diri, kepekaan, dan produktif.

\section{Kepustakaan}

Bintarto, Gathut. 2014. "Aspek Olah Vokal Musik Klasik Barat pada Musik Populer". Journal of Urbarn Society's Arts, 1 (1), p.44.

Jatmika, Ovan Bagus. 2016. "Suita Zodiak Komposisi Musik untuk String Kuartet dan Trio Woodwind.". Journal of Urbarn Society's Arts, 3 (1), p. 15.

Karbito, Nanang. 2015. Komposisi "Jangkah" Klonthong Laras Pelog. Resital: Jurnal Seni Pertunjukan, 16 (3), 166-173

Kaschub, M., dan Smith, J. 2009. Minds on Music: Composition for Creative and Critical Thinking. Maryland: MENC: The National Association for Music Education.

Mack, D. 2004. Sejarah Musik Jilid IV. Yogyakarta: Pusat Musik Liturgi.

Mills, J. 2005. Music in The School. New York: Oxford University Press.

Paynter, J. dan Aston, P. 1970. Sound and Silence. London: Cambridge University Press.

Prasetya, HB. 2013. Fisika Bunyi Gamelan. Yogyakarta: BP ISI

Swanwick, K. 1999. Teaching Music Musically. New York: Routledge.

Suneko, Anon. 2016. Komposisi Karawitan Pyang Pyung. Resital: Jurnal Seni Pertunjukan, 17(1), 5-7. 